\title{
Front Matter: Volume 8863
}

, "Front Matter: Volume 8863," Proc. SPIE 8863, Cryogenic Optical Systems and Instruments 2013, 886301 (10 October 2013); doi: 10.1117/12.2046521

SPIE Event: SPIE Optical Engineering + Applications, 2013, San Diego, California, SPIE. United States 


\section{PROCEEDINGS OF SPIE}

\section{Cryogenic Optical Systems and Instruments 2013}

James B. Heaney

E. Todd Kvamme

Editors

29 August 2013

San Diego, California, United States

Sponsored and Published by

SPIE

Volume 8863

Proceedings of SPIE 0277-786X, V. 8863

SPIE is an international society advancing an interdisciplinary approach to the science and application of light.

Cryogenic Optical Systems and Instruments 2013, edited by James B. Heaney,

E. Todd Kvamme, Proc. of SPIE Vol. 8863, 886301 - (C) 2013 SPIE

CCC code: $0277-786 \mathrm{X} / 13 / \$ 18 \cdot$ doi: $10.1117 / 12.2046521$

Proc. of SPIE Vol. $8863886301-1$

Downloaded From: https://www.spiedigitallibrary.org/conference-proceedings-of-spie on 26 Apr 2023 Terms of Use: https://www.spiedigitallibrary.org/terms-of-use 
The papers included in this volume were part of the technical conference cited on the cover and title page. Papers were selected and subject to review by the editors and conference program committee. Some conference presentations may not be available for publication. The papers published in these proceedings reflect the work and thoughts of the authors and are published herein as submitted. The publisher is not responsible for the validity of the information or for any outcomes resulting from reliance thereon.

Please use the following format to cite material from this book:

Author(s), "Title of Paper," in Cryogenic Optical Systems and Instruments 2013, edited by James B. Heaney, E. Todd Kvamme, Proceedings of SPIE Vol. 8863 (SPIE, Bellingham, WA, 2013) Article CID Number.

ISSN: 0277-786X

ISBN: 9780819497130

Published by

SPIE

P.O. Box 10, Bellingham, Washington 98227-0010 USA

Telephone +1 3606763290 (Pacific Time) · Fax +1 3606471445

SPIE.org

Copyright @ 2013, Society of Photo-Optical Instrumentation Engineers.

Copying of material in this book for internal or personal use, or for the internal or personal use of specific clients, beyond the fair use provisions granted by the U.S. Copyright Law is authorized by SPIE subject to payment of copying fees. The Transactional Reporting Service base fee for this volume is $\$ 18.00$ per article (or portion thereof), which should be paid directly to the Copyright Clearance Center (CCC), 222 Rosewood Drive, Danvers, MA 01923. Payment may also be made electronically through CCC Online at copyright.com. Other copying for republication, resale, advertising or promotion, or any form of systematic or multiple reproduction of any material in this book is prohibited except with permission in writing from the publisher. The CCC fee code is 0277-786X/13/\$18.00.

Printed in the United States of America.

Publication of record for individual papers is online in the SPIE Digital Library.

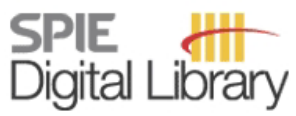

SPIEDigitalLibrary.org

Paper Numbering: Proceedings of SPIE follow an e-First publication model, with papers published first online and then in print and on CD-ROM. Papers are published as they are submitted and meet publication criteria. A unique, consistent, permanent citation identifier (CID) number is assigned to each article at the time of the first publication. Utilization of CIDs allows articles to be fully citable as soon as they are published online, and connects the same identifier to all online, print, and electronic versions of the publication. SPIE uses a six-digit CID article numbering system in which:

- The first four digits correspond to the SPIE volume number.

- The last two digits indicate publication order within the volume using a Base 36 numbering

system employing both numerals and letters. These two-number sets start with 00, 01, 02, 03, 04, $05,06,07,08,09,0 A, 0 B \ldots 0 Z$, followed by 10-1Z, 20-2Z, etc.

The CID Number appears on each page of the manuscript. The complete citation is used on the first page, and an abbreviated version on subsequent pages. Numbers in the index correspond to the last two digits of the six-digit CID Number. 


\title{
Contents
}

\author{
$\checkmark$ Conference Committee \\ vii Introduction
}

\section{SESSION 1 CRYOGENIC COOLERS AND MECHANISMS}

886302 Raytheon low temperature RSP2 cryocooler airborne testing [8863-2]

B. R. Schaefer, L. Bellis, M. J. Ellis, T. J. Conrad, Raytheon Space and Airborne Systems (United States)

886303 Advanced regenerator testing in the Raytheon dual-use cryocooler [8863-3]

B. R. Schaefer, L. Bellis, M. J. Ellis, T. J. Conrad, Raytheon Space and Airborne Systems (United States)

886304 Raytheon's next generation compact inline cryocooler architecture [8863-4]

B. R. Schaefer, L. Bellis, M. J. Ellis, T. Conrad, Raytheon Space and Airborne Systems (United States)

886305 Cryomechanism: a cryogenic rotating actuator [8863-5]

J.-C. Barriere, M. Berthé, M. Carty, B. Duboué, J. Fontignie, D. Leboeuf, J. Martignac,

C. Cara, P. Charon, G. A. Durand, D. Bachet, Commissariat à l'Énergie Atomique (France)

886306 Cryogenic optical position encoders for mechanisms in the JWST optical telescope element simulator (OSIM) [8863-6]

D. B. Leviton, NASA Goddard Space Flight Ctr. (United States); T. Anderjaska, Northrop Grumman Aerospace Systems (United States); J. Badger, Ball Aerospace and Technologies Corp. (United States); T. Capon, NASA Goddard Space Flight Ctr. (United States); C. Davis, Orbital Sciences Corp. (United States); B. Dicks, Ball Aerospace and Technologies Corp. (United States); W. Eichhorn, NASA Goddard Space Flight Ctr. (United States); M. Garza, Orbital Sciences Corp. (United States); C. Guishard, NASA Goddard Space Flight Ctr. (United States); S. Haghani, Northrop Grumman Aerospace Systems (United States); C. Hakun, P. Haney, NASA Goddard Space Flight Ctr. (United States); D. Happs, Ball Aerospace and Technologies Corp. (United States); L. Hovmand, Northrop Grumman Aerospace Systems (United States); M. Kadari, Jackson and Tull (United States); J. Kirk, Orbital Sciences Corp. (United States); R. Nyquist, Ball Aerospace and Technologies Corp. (United States); F. D. Robinson, Orbital Sciences Corp. (United States); J. Sullivan, Ball Aerospace and Technologies Corp. (United States); E. Wilson, Genesis Engineering Solutions, Inc. (United States)

\section{SESSION 2 CRYOGENIC OPTICAL PROPERTIES I}

886307 Temperature-dependent refractive index of Cleartran ZnS to cryogenic temperatures [8863-7]

D. B. Leviton, B. J. Frey, NASA Goddard Space Flight Ctr. (United States) 
886308 Temperature-dependent refractive index measurements of S-FPL51, S-FTM16, and S-TIM28 to cryogenic temperatures [8863-8]

D. B. Leviton, B. J. Frey, R. M. Henry, NASA Goddard Space Flight Ctr. (United States)

886309 Cryogenic refractive index and coefficient of thermal expansion of S-TIH1 glass [8863-9] M. A. Quijada, D. B. Leviton, D. A. Content, NASA Goddard Space Flight Ctr. (United States)

\section{SESSION $3 \quad$ CRYOGENIC OPTICAL PROPERTIES II}

8863 OA Properties of cathodoluminescence for cryogenic applications of $\mathrm{SiO}_{2}$-based space observatory optics and coatings [8863-11]

A. Evans Jensen, J. R. Dennison, G. Wilson, J. Dekany, Utah State Univ. (United States); C. W. Bowers, NASA Goddard Space Flight Ctr. (United States); R. Meloy, MEl Technologies, Inc. (United States); J. B. Heaney, Stinger Ghaffarian Technologies, Inc. (United States)

8863 OB Diverse electron-induced optical emissions from space observatory materials at low temperatures [8863-12]

J. R. Dennison, A. Evans Jensen, G. Wilson, J. Dekany, Utah State Univ. (United States); C. W. Bowers, NASA Goddard Space Flight Ctr. (United States); R. Meloy, ASRC Federal Holding Co. (United States)

\section{SESSION 4 SPACE INSTRUMENT CRYOGENIC SYSTEMS}

8863 OD The development and analysis of cryogenic optical systems for the rapid infrared imager/spectrometer [8863-14]

J. I. Capone, Univ. of Maryland, College Park (United States); D. A. Content, NASA Goddard Space Flight Ctr. (United States); O. D. Fox, NASA Goddard Space Flight Ctr. (United States) and Univ. of California, Berkeley (United States); N. A. Gehrels, NASA Goddard Space Flight Ctr. (United States); A. S. Kutyrev, Univ. of Maryland, College Park (United States) and NASA Goddard Space Flight Ctr. (United States); G. N. Lotkin, NASA Goddard Space Flight Ctr. (United States) and Global Science and Technology, Inc. (United States); S. H. Moseley, NASA Goddard Space Flight Ctr. (United States); F. D. Robinson, NASA Goddard Space Flight Ctr. (United States) and Global Science and Technology, Inc. (United States); V. L. Toy, S. Veilleux, S. N. Vogel, Univ. of Maryland, College Park (United States)

8863 OE NIRCam cryo filter wheel assembly design and performance [8863-15] C. S. Clark, B. I. Privári, Lockheed Martin Space Systems Co. (United States)

8863 OF JWST NIRCam pick-off mirror grounding [8863-16]

H. Demroff, P. V. Mammini, M. S. Jacoby, B. Jones, S. Hu, R. Dammann, J. Mathieson, Lockheed Martin Space Systems Co. (United States)

8863 OG Gaia basic angle monitoring system [8863-18]

W. Gielesen, D. de Bruijn, T. van den Dool, F. Kamphues, J. Mekking, TNO (Netherlands);

B. Calvel, A. Laborie, C. Coatantiec, S. Touzeau, EADS Astrium (France); M. Erdmann,

P. Gare, D. Monteiro, European Space Research and Technology Ctr. (Netherlands) 


\section{Conference Committee}

Program Track Chair

Oswald H. Siegmund, University of California, Berkeley (United States)

Conference Chairs

James B. Heaney, Stinger Ghaffarian Technologies, Inc. (United States)

E. Todd Kvamme, Lockheed Martin Space Systems Company (United States)

Conference Program Committee

David Chaney, Ball Aerospace \& Technologies Corporation

(United States)

Theodore D. Swanson, NASA Goddard Space Flight Center (United States)

\section{Session Chairs}

1 Cryogenic Coolers and Mechanisms

James B. Heaney, Stinger Ghaffarian Technologies, Inc. (United States)

2 Cryogenic Optical Properties I

James B. Heaney, Stinger Ghaffarian Technologies, Inc. (United States)

3 Cryogenic Optical Properties II

E. Todd Kvamme, Lockheed Martin Space Systems Company (United States)

4 Space Instrument Cryogenic Systems

E. Todd Kvamme, Lockheed Martin Space Systems Company (United States) 


\section{Introduction}

This volume is the Proceedings from our 15th biennial series of conferences on Cryogenic Optical Systems and Instruments. This year's conference was held in San Diego on 29 August 2013, as a part of SPIE Optics + Photonics symposium. Previous books in this series include: SPIE volumes 509 (1984), 619 (1986), 973 (1988), 1340 (1990), 1765 (1992), 2227 (1994), 2814 (1996), 3435 (1998), 4131 (2000)', 4822 (2002), 5172 (2003), 5904 (2005), 6692 (2007), 7439 (2009)2, and 8150 (2011). Taken together, these yellow-covered Proceedings are a veritable library documenting more than a quarter century of technological advances related to the design, development, testing, and performance of optical components and instruments and the mechanisms and techniques used to cool and maintain them at cryogenic temperatures. The international community is well represented in their contents.

From the beginning, the needs of the aerospace community have had a formative influence on the evolution of this technology. Space satellite missions such as UARS, COBE, SIRTF (Spitzer), Cassini, WMAP, the evolving JWST, and many others have contained instrumentation that was required to operate in some cases at temperatures near absolute zero. Their design, testing and performance evaluation challenged their cryogenic engineering and forced an advancement of the state-of-the-art. In our most recent conferences dating back to 2005, NASA's JWST mission, with its joint NASA/ESA instrumentation suite, has contributed significantly to the contents of SPIE Vols. 5904, 6692, 7439*, 8150, and this current volume. A statement of the challenges confronted and the clever engineering remedies applied can be found in the papers contained in their Proceedings. In our age when digital publishing and record archiving have forced institutions of all types to re-evaluate their methods of capturing institutional knowledge, we are privileged with these Proceedings to be part of the SPIE's Digital Library that can make the fruit of our labor permanently and readily available to all.

For the first time in this series of conferences, the editors have established a website - www.cryooptics.com - that is intended to be a gathering place for community ideas and a bulletin board for cryo-data, web links, and informal reports and related documents that will appear in the two years between our formal SPIE sponsored conferences. The website is currently live, but it is still under development. It is ultimately intended to act as an every-day hub for this conference.

E. Todd Kvamme James B. Heaney

1 Joint with Infrared Spaceborne Remote Sensing VIII

2 Joint with Astronomical and Space Optical Systems 